Walisongo Law Review (Walrev), Vol 2 No. 1 (2020)

DOI: 10.21580/walrev/2020.2.1.5530

Copyright @ 2020 Walisongo Law Review (Walrev)

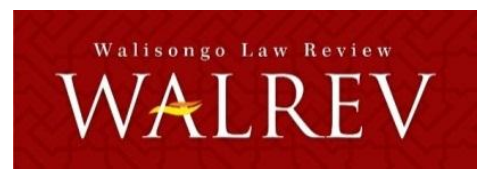

\title{
Annual Leave Entitlement of Labor (A Comparison between Egypt Law with Indonesia)
}

\author{
Jaedin \\ Afiliasi: Universitas Kristen Satya Wacana, Salatiga \\ e-mail: jaedin_zidane@gmail.com
}

\begin{abstract}
Wages are unimportant in work ties then leave pay is a worker's right that must be provided in accordance with the principle of no work no pay. Leave is a goal to restore labor to a physically stable and able to rest the human body. However, the regulations in Indonesia do not apply the law as in the State of Egypt, the employer revokes the wages of leave if the worker is provided with other services while on leave. Regulations in Egypt are in accordance with the Egyptian Law Number 12 of 2003 concerning relevance to the purpose of the leave itself, namely leave to rest the physical or body of the worker, not to utilize work leave at another employer. However, the regulations in Indonesia in Law Number 13 of 2003 have not been regulated as in Egypt. In Egypt, it is more comprehensive in expressing the principle of no work, no pay.
\end{abstract}

Upah merupakan unsur penting dalam ikatan kerja kemudian upah cuti adalah hak pekerja yang harus diberikan hal ini sesuai dengan prinsip no work no pay. 
Cuti merupakan sebuah tujuan untuk mengembalikan tenegakerja pada fisik yang stabil serta dapat mengistirahatkan tubuh manusia. Namun pada peraturan di Indonesia belum memberlakukan hukum seperti di Negara Mesir, pengusaha mencabut upah cuti jikda didapatkan si pekerja bekerja dimajikan lain saat cuti berlangsung. Peraturan di Mesir sesuai Egyptian Law No 12, 2003 lebih relevan dengan tujuan cuti itu sendiri, yakni cuti untuk mengistirahtkan fisik atau tubuh si pekerja, bukan untuk memanfaatkan cuti bekerja di majikan lain. Namun dalam peraturan di Indonesia dalam UU No 13 Tahun 2003 tentang Ketenagakerjaan belum diatur seperti yang ada di Mesir. Di Mesir lebih komprehensip dalam menuangkan prinsip no work no pay.

Keyword: Work Leave; Wages; Labor

\section{Introduction}

Labor problems are never finished, new problems always arise, both in terms of regulation or in terms of discrepancies between workers and employers themselves. Regulatory problems usually occur with discrimination. Whereas the problem of workers with the promotion of the lack of uniformity between work relationships, the existence of rights and obligations that are not fulfilled. Labor problems are not only in Indonesia. Labor problems also occur in various countries, both developing countries and developed countries. The most frequently occurring labor problem is the issue of wages.

Labor wage problems also exist in the State of Egypt, discrimination is still occurring between men and women in the workplace, as well as including wage discrimination. In Egypt inequality increased from 1988 to 2006, in 2012 there was a decrease in wage inequality as measured by the decline ratio. Inequality remains above the 1988 and 1998 levels, but below the 2006 level, until in 2012 after two decades of privatization and structural adjustment programs, the Egyptian labor market seems to have been better off to pre-adjust the real wage level (Said 2015:3). 
The author here will point to one of the differences in wage provisions in Egypt in 2003 in English "The Egyptian Labor Law Number 12 for the year 2003 "then the name will be abbreviated to Labor Law Number 12 of 2003 with National Law, which refers to the Manpower Act in Indonesia. In particular, the author will further review the "right of vacation leave wages" for workers, which basically every worker can get a salary in work time that has been determined by the company.

The reason for the Egyptian state being the basis of comparison is because in the context of the states of Indonesia and Egypt have similarities in regulation on Manpower. Indonesia and Egypt both ratified the International Labor Organization (ILO) which was implemented in law. Similarities between the Egyptian people and Indonesia are both Muslim majorities, but the labor regulations do not impose Islamic requirements.

Work/vacation leave wages are included in the no work no pay principle. In Indonesia then this principle is further elaborated in Article 93 of Law Number 13 of 2003 concerning Labor, Paragraph (1) says that wages are not paid if workers do not do work. Paragraph (2) explains that the provisions referred to in paragraph (1) do not apply, and the employer is obliged to pay wages if; letter $\mathrm{g}$. which states that workers/laborers exercise the right to rest.

Then interpreted more broadly in Article 24 PP Number 78 of 2015 concerning Wages as referred to in paragraph (1) that "Wages are not paid if the Worker/Laborer does not come to work and/or does not do work. There are exceptions as in Paragraph (5) Workers/Laborers do not come to work and/or do not do work because they exercise their right to work as referred to in paragraph (2) letter $\mathrm{c}$ if the Worker/Laborer carries out: a. weekly resting rights; b. annual leave; c. long break; d. prenatal and post-natal leave; or e. pregnancy miscarriage leave ".

Whereas in Egypt there is a clause not getting paid leave if the worker works for another employer, on the day the leave takes place. In accordance with Article 50, Labor Law Number 12 of 2003 explains 
the right to rest or paid worker's rest wages, as well as wages not given if Article 50 is violated stating that, "The employer can deprive the worker of his salary during the vacation or recover the wages he has paid if he is proven to be employed by another employer, without reducing sanctions disciplinary". The difference in the labor law there is no clause which states that if on the day of leaving the worker works for another employer, he will not get paid leave, whereas in Egypt vice versa. The regulations in Egypt are not given wages for working at other employers when this leave forms an injustice.

For this reason, the author will look further into the nature and purpose of the leave itself for workers, which results in the issue of workers' wages. The right to pay for work leave seems important to be discussed further to see that regulations regarding employment in Indonesia are said to be fair and whether or not. This type of research is a normative philosophical type of juridical, and qualitative. Normative juridical research addresses doctrines or principles in the science of law. According to Holland the importance of the scope of legal comparison is limited to descriptive research, according to Holland's research results submitted to legal experts to be analyzed or applied to concrete situations. According to Van Apelddron, comparative law is an auxiliary science for dogmatic jurisprudence in the sense that to weigh and assess existing legal rules and court decisions with other legal systems (Marzuki 2005:124).

\section{Discussion}

\section{Overview of Wage Protection}

In Indonesia, the state is present for the purpose of regulating and providing protection for workers so that they get a living wage in accordance with the mandate of the 1945 Constitution. Article 27 paragraph (2) of the 1945 Constitution states that "every citizen has the right to work and a decent living for humanity ". Then also regulated in Article $28 \mathrm{D}$ paragraph (2), every person has the right to work and receive fair and appropriate treatment and benefits in an 
employment relationship" (Pemerintah RI 1945). This means that remuneration in the field of labor is regulated by the constitution.

Guaranteed decent wages are the main things in life, and there is no difference between men and women in terms of getting work and wages. In Article 38 of Law Number 39 of 1999 concerning Human Rights paragraph (1) states that "Everyone has the right, in accordance with their talents, skills, and abilities, entitled to decent work". Next paragraph (2) states "Everyone has the right to freely choose the work he likes and is entitled to labor conditions". Obtain equal rights at work, equal, equal, in terms of employment agreements. Then not only can work in the dignity of humanity, but it is also entitled to both of them for a fair wage in accordance with their achievements and can guarantee the survival of their family life (RI 1999:Article 38).

Guaranteed wages for humanity are guaranteed in the Manpower Act Number 13 of 2003 concerning Manpower states that wages are workers' rights which are accepted and expressed in terms of money. Article 88 paragraph (1) states "Every worker/laborer has the right to earn an income that fulfills a decent living for humanity". Then paragraph (2) states "In order to realize income that fulfills a decent living for humanity as referred to in paragraph (1), the government establishes a wage policy that protects workers/laborers". This means that adequate wages are guaranteed for workers and are protected by law.

Wages are born from a contract that gives rise to rights and obligations for workers and employers. Workers must pay when the work is completed, then the employer is entitled to get the work according to the work agreement.

Pursuant to Article 1 number 15 of Law Number 13 of 2003 concerning Manpower, employment relations are relations between employers and workers or laborers based on work agreements that have elements of work, wages, and orders. The employment relationship is abstract and is a legal relationship between the employer and a worker or laborer. Work relations are only born 
because there is an employment agreement. The agreement gives birth to engagement, an engagement that is born because of this employment agreement which is an employment relationship (Rosali 2008:30).

Article 79 of Law Number 13 of 2003 concerning Manpower states that:

a. Employers are required to provide workers with time off and leave.

b. Rest and leave as referred to in paragraph (1), includes:

1) rest between working hours, at least half an hour after working for 4 (four) hours continuously and the rest period does not include working hours;

2) weekly rest 1 (one) day for 6 (six) working days in 1 (one) week or 2 (two) days for 5 (five) working days in 1 (one) week;

3) annual leave, at least 12 (twelve) working days after the relevant worker/laborer works for 12 (twelve) months continuously; and

4) long break of at least 2 (two) months and carried out in the seventh and eighth years of 1 (one) month each for workers/laborers who have worked for 6 (six) years continuously at the same company with the provisions of the worker / The worker is no longer entitled to his annual rest within 2 (two) current years and thereafter applies to any multiples of 6 (six) years work period.

c. The implementation of the annual rest period referred to in paragraph (2) letter $\mathrm{c}$ is regulated in a work agreement, company regulations, or collective work agreement. (4) The right to long rest as referred to in paragraph (2) letter d only applies to workers/laborers who work in certain companies. (5) Certain companies as referred to in paragraph (4) are regulated by Ministerial Decree.

Article 88 (1) paragraph (3) of Law Number 13 of 2003 concerning Manpower states that "wage policies that protect workers/laborers as referred to in paragraph (2) e. wages for exercising resting rights" (Pemerintah Mesir 2003:Article 88 (1)). Wages are not paid if the 
work is not worked, an exemption is contained in Article 93 paragraph (2) The provisions referred to in paragraph contained in point (1) state that "does not apply, and the employer is obliged to pay wages, and emphasizes point g. which states that "workers/laborers exercise the right to rest ...".

There are some notes regarding leave due to illness, according to several subsequent analyzes according to the explanation of Article 93 paragraph (2) letter a, what is meant by sick workers/laborers is as sick as according to doctor's statement. Therefore, it is indeed sick in this case must be proven by a certificate from a doctor. If there is no certificate from the doctor, then it is not included in the exemption from Article 93 paragraph (1) of the Manpower Act. So if you do not do work because of illness without a doctor's certificate, this is not entitled to receive wages. Moreover, there is a stipulation in the company where the worker works that absent workers without a doctor's letter are deducted from the base salary. if all of that cannot be proven then go back to Article 93 according to the principle of no work no pay.

Because of the importance of analyzing and seeing that the purpose of the leave is for the benefit of the workers and employers. Because even in the condition of leaving the worker the nature of the law is still in an agreement that still gives birth to rights and obligations.

\section{Comparison of the Applicable No Work No Pay Principle in Leave Rights in Indonesian and Egyptian Legal Regulations}

\section{a. An equation to Determine the No Work No Pay Principle}

Regarding equality in determining the principle of no work no pay, this emphasizes the issue of rights and obligations, which is based on a concept of justice for social cooperation, if rights and obligations are not carried out, as a result, a form of social cooperation will not be achieved. The goal of the cooperation is the mutual benefit of both parties. Then how to exercise rights and obligations in a balanced manner in work relationships, so 
that everyone has the opportunity to benefit from it and in real terms, and bear the same burden. Therefore, in order to ensure a balanced distribution of rights and obligations, referring to the principle of bankruptcy, Jhon Rawls also stressed the importance of a fair agreement among all members of the community. Only fair agreements can encourage social cooperation (Hasanuddin 2018:195).

There are several points in the principle of no work no pay, in Labor Law Number 12 of 2003 Egypt including. Pregnancy leaves article 88, breastfeeding leave Article 93, Weekly 83 vacation pay, Annual leave article 47.

And there is an interesting point in determining the principle of no work no pay, as explained at the beginning of the chapter, namely in Egypt, there is a clause not getting paid leave if the worker works for another employer, on the day the leave takes place. In accordance with Article 50 Labor Law Number 12 of 2003, Egypt explains the right to rest or paid worker's rest, and wages are not given if Article 50 is violated stating that, "The employer can deprive the worker of his salary during the holidays or recover the wages he has paid if he is proven to be employed by another employer, without reducing disciplinary sanctions ". The difference in the labor law there is no clause which states that if on the day of leaving the worker works for another employer, he will not get paid leave, whereas in Egypt vice versa. The regulations in Egypt are not given wages for working at other employers when this leave is a form of injustice.

In determining the principle of no work no pay in Article 93 of Law Number 13 of 2003 concerning Manpower concerning, which states that:

1. Female workers/laborers who are sick on the first \& second day of their menstruation;

2. carry out his educational duties from the company. Workers/laborers do not come to work because they are 
married, married, circumcised, baptized their children, the wife gives birth/miscarriage, etc;

3. Because it is carrying out obligations towards the state;

4. Because of performing the worship that is ordered by his religion;

5. Workers/laborers are willing to do the work that has been promised but the employer does not employ him, either because of his own mistakes or obstacles that should be avoided by the employer;

6. Workers/laborers exercise the right to rest; Carry out the tasks of the SP/SB with the approval of the entrepreneur;

Generally, in principle, in Labor Law Number 12 of 2003 Egypt and Law Number 13 of 2003 Indonesia has stated the rights and obligations between workers and employers/ employers. This means that both of them can be seen from the principle of no work no pay and can be seen in what contracts should be done by workers, and what are the rights of workers after doing and completing their work.

Article 93 of Law Number 13 of 2003 concerning Manpower regarding the principle of no work no pay, as a whole and systematically the points listed in the article are more complete and more comprehensive. Automatically more workers get more legal protection from wages.

\section{b. Differences Determine the No Work No Pay Principle}

Regarding rights and obligations born from an employment relationship, from the employment relationship so that rights and obligations are not mutually impaired in the form of a contract. Exceptions to the principle of no work no pay get protection and relief to workers.

The difference in structure and content of the points emphasizes the principle of no work no pay as explained above that one of the advantages in determining the principle in Indonesia is that it is more comprehensive and systematic in the principle of no work no pay. But there is also a side of this 
difference regarding the provisions of the principle of no work no pay including:

First, regarding the differences in substantial points in applying the principle of no work no pay. The State of Egypt places more emphasis on the aspects of violations committed by the Worker. In seeing the absence of wages if it does not work, it means that if the worker commits corruption or gratification to get money not according to his right to work, then it will automatically not get a salary from the company. So all workers' actions whether they are beneficial or detrimental must be in accordance with the employer's agreement. If you take action and will harm the company, then the punishment will not get a salary from the company. While in Indonesia there is no explanation or clause in the regulation.

There is one interesting point to be observed about the differences regarding the provisions of the principle of no work no pay. Namely about the difference in the "right of paid leave". In Indonesia the right to leave pay in accordance with Law Number 13 of 2003, protected by law, as well as in Egypt in Labor Law Number 12 of 2003 Egypt. But a significant difference in the two regulations, in Egypt there is a clause that states "if you want to work elsewhere, then you will lose the right to pay leave/rest. Whereas in Indonesia workers will still get the right to pay to leave even though they work using their time off, and there is no clause stating this.

Regarding differences in policy regarding leave pay above. On that basis we must see the purpose of leave or rest itself, the function and purpose of leave or rest we must understand. According to Rivai, physiological fatigue is fatigue that arises due to changes in body physiology. Body changes are from fresh to fatigued conditions that will affect employee performance optimization. Factors affecting energy recovery include the length of time of rest, rest period, and frequency of rest. Restoring the physiology of the body to return to a fresh condition during the activity is an important thing that needs to be considered, one of 
the factors that can affect energy recovery is a short break and not thinking about work. With the importance of wife to return to work with a state of body condition, fresh, fit, and can return to work optimally (Sulistyo, Natasya Ulfiyah, Mochammad Al Musadieq Muhammad 2018:10). In the leave regulations on employment recorded in the rules and regulations in the work.

The importance of taking time for the purpose of refreshing the mind that many bear the workload demanded by the company because the condition of the body that is not good for work should be important to be able to take time off work for rest and vacation in order to refresh the mind when bored from work. Forget the feeling of being reluctant or ashamed to ask permission to take time off from your boss to refresh your mind. The leave will provide benefits to ease the mind, improve morale, and restore productivity at work.

In Article 79 Paragraph 2 of Law Number 13 of 2013 (Manpower Law) concerning Manpower "Provisions regarding working hours, work breaks, and work leave of company employees have been definitively determined". Based on this law only employees who have worked for at least 12 months or 1 year are entitled to annual leave for 12 days, and therefore the company is authorized to refuse requests for employee leave that is not even 1 year of work (Sulistyo, Natasya Ulfiyah, Mochammad Al Musadieq Muhammad 2018:10).

So, in relation to getting full wage rights, what is meant by Article 79 paragraph (2) letter b is a weekly rest of 1 (day) if 6 hearts work in (1) Sunday or 2 (two) days for 5 (five) workdays in ( 1 week. And what is meant by letter $\mathrm{c}$ is annual leave which is a right of rest for workers for at least 12 (twelve) working days; the letter $\mathrm{d}$ is about rest/leave of view that only applies to workers who work in certain companies.

In seeing the explanation of Work Law Number 12 of 1948 the purpose of annual leave is seen as one of the opportunities for workers to use it to visit the family or to take a review trip with a 
view to refreshing the body and mind and broadening views (Widjajanto 2009:97).

By looking at the above objectives, with regard to regulations in Egypt they would not hurt if in Labor Law Number 12/2003 Egypt imposes fines on workers who when on leave work at another employer, the fine is not paid leave. Because remembering the purpose of the leave is to provide benefits to ease the mind, increase morale, and restore productivity at work.

As a result, if a worker is allowed to work for another employer while on leave, the worker will remain in exhaustion and result in not returning productivity to work when it is time to work for his employer.

At present the protection of the right to paid leave is based on the International Covenant on Economic, Social and Cultural Rights in Article 7, stated the right to enjoy fair and profitable offerings, and guarantees: fair pay and equal pay for work of equal value without distinction based on anything, especially for women guaranteed lower working conditions than men, with the same pay for the same job. In addition, a decent life for themselves and their families is in accordance with the provisions of this Convention. 1. Safe and healthy working conditions. 2. Equal opportunity for everyone to be promoted to a higher and appropriate level in their work, without realizing any consideration other than seniority and ability. 2. Vacation breaks and reasonable hours of work, and periodic holidays with salaries or other benefits on public holidays (Widjajanto 2009:10).

Then Based on Article 24 of the Universal Declaration of Human Rights 1948 (DUHAM), states: everyone has the right to rest and vacation, including restrictions on decent working hours, and periodic holidays by receiving wages.

This means that the policy of the State of Egypt regarding the protection of workers' leave rights is very strict. By looking at sanctions for those who work on leave. Approaching Justice Jhon Rawls, regulations in Egypt are closer to the fair agreement of 
what was initiated by John Rawls. This means that the rights and obligations will be maintained with the absence of leave to restore worker productivity when returning to work.

In Jhon Rawls's perspective of justice, the importance of rights and obligations is fulfilled, and how the importance of society wants to change in determining justice he states that:

I described briefly the principles of natural duty and obligation that apply to individuals. We must now consider why these principles would be chosen in the original position. They are an essential part of a conception of right: they define our institutional ties and how we become bound to one another. The conception of justice as fairness is incomplete until these principles have been accounted for. From the standpoint of the theory of justice, the most important natural duty is to support and to further just institutions. This duty has two parts: first, we are to comply with and to do our share in just institutions when they exist and apply to us; and second, we are to assist in the establishment of just arrangements when they do not exist, at least when this can be done with little cost to ourselves. It follows that if the basic structure of society is just, or as just as it is reasonable to expect in the circumstances, everyone has a natural duty to do what is required of him. Each is bound irrespective of his voluntary acts, performative or other-wise (Rawls 1971:294).

Rawls briefly explains the principles of duties and natural obligations that apply to individuals. We must now consider why these principles will be chosen in their original positions. They are an important part of the conception of rights: they define our institutional ties and how we become bound to one another.

From the standpoint of justice theory, nature's most important task is to support and promote equitable institutions. This task, in terms of context (working society), has two parts: first, we must obey and do our part in fair institutions when they exist and apply to us; and second, we must help in setting fair arrangements when there are none, at least when this can be done at a small cost to 
ourselves. Therefore, if the basic structure of society is fair, or as it is fair to be expected under circumstances, everyone has a natural obligation to do what is asked of him. Each is bound regardless of voluntary, performative, or other actions.

What has been enacted in Egypt, to reconstruct labor laws is a new option in determining the rules and provisions of the principle of no work no pay, especially regarding the right to pay leave/rest.

\section{Conclusion}

Both the Egyptian and Indonesian laws have emphasized the principle of no work no pay in work relations. To protect the rights of workers and employers. Article 24 of the Universal Declaration of Human Rights 1948 (DUHAM) states: everyone has the right to rest and vacation, including restrictions on adequate working hours, and periodic holidays by receiving wages.

Whereas in the difference, in Egypt it looks more relevant when workers do not get paid because when on leave work at another employer. See that leave is the right of workers and their wages, and see the purpose of the leave itself that is to restore a stable physique and take rest and maintain a healthy body. Bearing in mind one of the objectives of leave as stipulated in Work Law Number 12 of 1948 the purpose of annual leave is seen as an opportunity for laborers to use it to visit the family or to take a review trip with a view to refreshing the body and mind and broadening views. For this reason, Indonesia should implement regulations like those in Egypt. Punish workers who are not paid work leave pay if found working at another employer. To achieve a leave goal in the principle of no work no pay. $[\mathrm{w}]$

\section{Reference}

Hasanuddin, Iqbal. 2018. "Keadilan Sosial: Telaah Atas Filsafat Politik John Rawls." Refleksi 2:195. 
Marzuki, Peter Mahmud. 2005. Penelitian Hukum. Jakarta: Kencana Prenada Media Group.

Pemerintah Mesir. 2003. "Egyptian Labor Law Number 12 of 2003."

Pemerintah RI. 1945. "Undang-Undang Dasar RI Tahun 1945.”

Rawls, Jhon. 1971. A Theory Of Justice. USA: Harvard University Press.

RI, Pemerintah. 1999. "Undang-Undang RI Nomor 39 Tahun 1999 Tentang Hak Asasi Manusia."

Rosali, Devita Christi. 2008. "Pelaksanaan Hubungan Kerja Antara Pengusaha Dan Pekerja Dalam Kaitannya Dengan Aspek Norma Kerja Di Solopos.” Universitas Sebelas Maret Surakarta.

Said, Mona. 2015."Wage and Inequality in The Egyptian Labor Market An Era Financial Crisis And Revolution."

Sulistyo, Natasya Ulfiyah, Mochammad Al Musadieq Muhammad, Cahyo Widyo. 2018. "Peranan Cuti Kerja Dalam Rangka Mengurangi Stres Kerja Karyawan" (Studi Pada Karyawan PT. Perusahaan Daerah Air Minum." Jurnal Administrasi Bisnis 61(1).

Widjajanto, Dedy. 2009. "Pengaturan Waktu Kerja Dan Waktu Istirahat Sebagai Perlindungan Bagi Buruh/Pekerja (Studi Kasus Di Beberapa Perusahaan).” Universitas Indonesia. 